\title{
Discourse Analysis as a Means to Scrutinize REDD+: An Issue of Current Forest Management Debate of Nepal
}

\author{
Dilli Prasad Poudel ${ }^{1}$ and Tor Halfdan Aase ${ }^{2}$ \\ ${ }^{1,2}$ Department of Geography, University of Bergen-Norway \\ Corresponding author: dilli.poudel@gmail.com
}

\begin{abstract}
This article shows how discourse analysis can be a methodological tool to scrutinize texts under the aegis of Reducing Emissions from Deforestation and Forest Degradation, sustainable management of forest, and conservation and enhancement of carbon (REDD+). A discourse is a perspective of an individual or an organization, which always tries to achieve a dominant position in the society. Texts used in discourses are impossible to understand properly in isolation. They are the reflections of social practices. Discourses, which contain multiple meanings, are also used as devices to make texts meaningful in regular communication. Analysis of discourses is called discourse analysis. Laclau and Mouffe (1985) believe that social structures (norms, rules and institutions) are created by pre-existing discourses of society, thereby we humans conceive objective reality according to the existing discourses. Alternatively, Fairclough (1995) believes that discourses not only reflect social structure but are also bounded by them. Both perspectives have been used as methodologies to analyse discourses, nonetheless Fairclough's discourse analysis is more pragmatic than Laclau and Mouffee's. The term 'REDD+' implies a discourse about forming new forestry institution in developing countries like Nepal, which is articulated in the name of mitigating deteriorating climate of the world. We suggest combining both perspectives to scrutinize the issue like REDD+. We found that discourse analysis is a suitable method to scrutinize REDD+ in the Nepalese context where people consider forest as a vital source of earning livelihoods and the foundation of sustaining local environment.
\end{abstract}

Key words: Forest management, discourse analysis, REDD+, polysemous, hegemonic existence, Nepal

\section{INTRODUCTION}

Reducing Emissions from Deforestation and Forest Degradation, sustainable management of forest, and conservation and enhancement of carbon (REDD+) is an international climate policy framework, which aims to establish an economic value of protected and better managed forests especially in the developing countries for storing carbon and not emitting it in the atmosphere (Corbera and Schroeder 2011). Initially, REDD+ was proposed as an agenda of Reducing Emissions from Deforestation (RED) at the $11^{\text {th }}$ Conference of the Parties (COP-11) to the United Nations Framework Convention on Climate Change (UNFCCC) in 2005 in Montreal (Canada) by the submission of Papua New Guinea and Costa Rica (UNFCCC 2006). At present, carbon emissions, forest regeneration and rehabilitation, sustainable management, biodiversity conservation, enhancement of forest carbon stock in developing countries, and social safeguards have also been included in the RED framework (Angelsen 2009; Chhatre et al. 2012; Venter and Koh 2012; VisserenHamakers et al. 2012; Wallbott 2014). These updates are abbreviated as the second ' $\mathrm{D}$ ' and '+' sign and termed 'REDD+' at present. Since then, REDD+ has emerged in regular communication and many developing nations, including Nepal, have ratified it as a new way of earning money through forest management. The following arguments are frequently used to convince developing nations to implement REDD+ in their territory:

- Eliminating most deforestation would cost US $\$ 1-2$ per ton Carbon Dioxide $\left(\mathrm{CO}_{2}\right)$ on average (Stern 2006: cited in Angelsen and MacNeill 2012; Wolf 2013), which is more inexpensive than other mitigation options;

- In 2007, The Intergovernmental Panel on Climate Change (IPCC) estimated that emission from deforestation was about $5.8 \mathrm{Gt} \mathrm{CO}_{2}$ (gigatonnes of carbon dioxide) annually, which is 
about 20 per cent of global total during 1990s (Wollenberg and SpringateBeginski 2010). This means about 20 per cent $\mathrm{CO}_{2}$ can be sequestered just by conserving forest, which motivated industrialized nations to invest money in the poor nations in the name of conserving environment (Wolf 2013);

- REDD+ is also presented as a programme where forest owners can earn more money by protecting forest and sequestering carbon than by selling forest (Sunderlin and Atmadja 2009: cited in Angelsen and MacNeill 2012); and

- REDD+ is considered as a multipurpose option to counteract increasing global warming, and to contribute to environmental as well as development goals (Angelsen and MacNeill 2012; Luttrell et al. 2013).

Based on our literature review, we also think that these are the main motivating or convincing logics which are ostensively used to pilot REDD+ projects in developing nations and the efforts at persuading developing nations to join the REDD+ programme can be seen as a discourse. At present, REDD+ establishes a myth as a panacea to combat carbon emission, control poverty, and avoid biodiversity degradation (a triple 'win') (Angelsen and MacNeill 2012; Luttrell et al. 2013).

Government of Nepal has been involved in REDD+ by submitting the ReadinessPlan Idea Note (R-PIN) in March 2008 and Readiness Preparation Proposal (R-PP) in April 2010 to the World Bank's Forest Carbon Partnership Facility (FCPF). The main actors of REDD+ policy process in Nepal are presently REDD-Cell under the Ministry of Forest and Soil Conservation (MoFSC), consultants employed to prepare the policy document, International Non-Governmental
Organizations (INGOs), donor agencies, Civil Society Organizations (CSOs), such as FECOFUN, NEFIN ${ }^{1}$ (Bushley and Khatri, 2011; Ojha et al. 2013; Paudel et al. 2015). Some literature claim that REDD+ brings positive changes to the rural communities (Wollenberg and Springate-Beginski 2010) while others believe that it negatively impacts local communities by commoditizing locally sustained forests (Corbera 2012; Fairhead et al. 2012). Yet others suspect that it delinks villagers from their forests and creates antagonistic relations among villagers (Poudel 2014; Poudel et al. 2014) and can therefore be a source of community level conflict (Patel et al. 2013). Yet others believe that REDD+ is still immature and needs re-adjustment on its original concept (Pokorny et al. 2013). All these arguments claim to be valid descriptions of realities regarding REDD+. Now the question remains on whose knowledge should be counted then. In the following sections, we investigate if discourse analysis can be a useful methodological tool to scrutinize the texts under the aegis of REDD+ in Nepal.

\section{BASIS OF DISCOURSE ANALYSIS}

A discourse is a particular way of talking and understanding about the world (or an aspect of the world) (Jørgensen and Phillips 2010). A discourse can simply emerge through a talk or discussion which is fixed - relying on cultural and political context - by an individual or an organization to produce an intended meaning. A discourse is also an attempt to fix a web of meanings within a particular domain (Laclau and Mouffe 1985). Therefore, an emergence of discourse can be seen as an exercise of power (Howarth and Stavrakakis 2000: cited in Rear 2013). Discourses are also different perspectives of a different group of social actors, such as in politics, medicine, social welfare, academia and so forth (Fairclough 2012). More than one discourse exists at a time in a particular socio-ecological context. A study of discourse is called 'Discourse Analysis'. 
Reality can be so complex that equally valid observations from differing perspectives can appear to be contradictory.

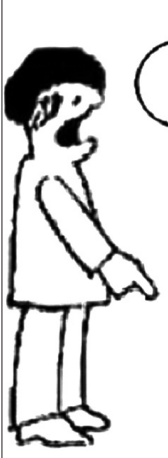

Four

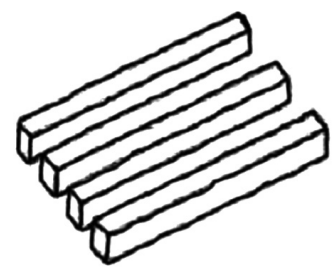

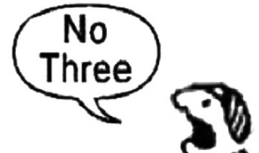

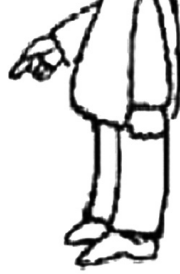

Figure 1: Perspectives Regarding a Reality $^{2}$

Discourse analysis contends that discourses are a form of social action that produce the social world including knowledge, identities and social relations and thereby maintain specific social patterns (Jørgensen and Phillips 2010). A discourse conceives that knowledge is contingent because it can only be generated through interactions. In other words, knowledge about the social world is discursively produced through social process and interaction, which thereby guides individual actors to distinguish between true or false knowledge. Varieties of discursive social processes to generate knowledge about the world produce varieties of actions which can be natural for someone and unnatural to others. Figure 1, for instance, illustrates the existence of two perceptions of an object which are equally real from their sides.

Discourse analysis is especially used in the 'structuralist' and 'post-structuralist' approaches. The structuralists are closely associated with Marxism and post-structuralists are associated with Foucault's concept of power. However, Marxism and Foucault's power are beyond the analysis of this article. Here, we shall focus on two kinds of discourse analyses which are widely applied today.
Structuralist discourse analysts assume the existence of social structures (norms, rules, regulations and institutions) or rule-bound society exist prior to emergence of discourses. They pre-suppose a class-based 'subject' or identity of individuals (Dittmer 2010). However, they assume that the knowledge and identities are always contingent (Jørgensen and Phillips 2010). On the other hand, poststructuralist discourse analysts, on their part, disregard existence of rule-bound society prior to discourses; instead, they believe that society is the creation of pre-existing discourses (Jørgensen and Phillips 2010). In addition, they see the individual itself as a subject whose identities are formulated through discursive processes (Dittmer 2010).

Both structuralist and post-structuralist discourse analysts have considered 'language' as a medium of production and transformation of knowledge. This is because, language, according to Searle (2005) has the following qualities: (1) The ability to communicate meaning. For instance, REDD + gains institutional value in the society due to its new approach to manage forest; (2) Language contains deontic power which relates to rights, duties, obligations, authorizations, permissions, empowerments, requirements, and certifications. For instance, unlike animals, humans can distinguish between an ordinary person and the president by their status, although both are human beings; (3) Recognition of meaning of status remains continuous through language; (4) Language is the only medium through which other institutions, such as government, market, property, and social clubs can be recognized; and (5) Language is also a mechanism to motivate groups of individuals collectively.

The strong role of language in discourse analysis is actually based on the concept of 'sign', which was postulated by Ferdinand de Saussure (see, Fiske, 1990), a linguist. According to him, a 'sign' can be defined as "something

\footnotetext{
${ }^{2}$ This figure has been adopted from www.facebook.com (accessed on 8 Feb, 2015)
} 
that stands for something else", like the word 'dog' which refers to a certain animal. For Saussure, a certain sign must be explained by other signs to become meaningful (Fiske 1990). A word gains its meaning in relation to other words. Jørgensen and Phillips (2010) use the term 'fishing net' as a metaphor to analyse the signs of Ferdinand de Saussure. In 'fishing net', all individual loops have a fixed position and are attached to each other. Likewise, signs or words have fixed meaning and position in any structured language.

A word linked to an object is a social construction; a word (sign) and an object (signified) have no natural connection. We attach meaning to objects by ascribing words to them. The relation between 'signifier' and 'signified' is context-sensitive and intersubjective. For instance, the word 'forest' has no natural connection with 'actual forest' which appears in our cognitive mind when someone utters the word 'forest' or shows an image of 'forest'. Fiske (1990) says that a sign is something physical, perceivable by our senses. It refers to something other than itself and it depends upon recognition by its users. The word 'forest' gains different meaning if we use it in different contexts. For instance, 'a city of concrete forest' does not mean actual natural forest rather it means 'crowd of buildings and houses in a city'. So, a sign achieves meaning depending upon the context in which it is used. Some signs obtain meaning through a relation with the object they are meant to represent, like a photo or a sculpture. But other signs have only arbitrary relations to objects, like words. Words are thus, the special type of signs which are called symbols. Both structuralist and post-structuralist discourse analysts apply the concept of arbitrary relation between symbols and arbitrary relation between language and reality (Jørgensen and Phillips 2010).

In discourse analysis, unlike Saussure, the meaning and position of signs are considered with their context of use. So, signs can achieve different meaning through articulation. Articulation is an act or process of establishing relations between signs where independent meaning of signs are modified. And discourse analysis discloses the process of formation of meaning of signs, which are arbitrary in nature, in various discourses of society (Jørgensen and Phillips 2010).

The terms used to define REDD+ (see introduction) are based on interpretation of climate change, forest management, carbon trade, poverty, and livelihoods, which must be re-interpreted to generate knowledge. These interpretations are also based on expressions or network of words which are symbolic. Because words are symbols, and are representations, they should be treated as 'signs' in discourse analysis. Among various theories about discourse analysis, Laclau and Mouffe's (1985) theory and Fairclough's (1995) critical discourse analysis (CDA) are well recognized (Dittmer 2010; Jørgensen and Phillips 2010; Rear 2013; Taylor 2013). The following sections deal with the methodological aspects of these theories and try to relate them to the Nepalese context of REDD+ process.

\section{DISCOURSE ANALYSIS AS A METHOD TO SCRUTINIZE REDD+}

Laclau and Mouffe (1985) consider that social identities are created by pre-existing discourses of society. Even our perception of existing realities and characteristics of real objects is entirely mediated by pre-existing discourses; thereby, we humans cannot conceive of objective reality outside existing discourses (cited in Rear 2013). Unlike Saussure, Laclau and Mouffe consider that in the study of production of objective reality, the meaning of 'signs' are arbitrary and always the matter of negotiation in day-to-day interaction. But as Saussure believes, they also consider that the position of signs remain fixed in order to attain proper meaning. 
According to Laclau and Mouffe (1985), a discourse is the result of articulatory practice (cited in Rear 2013). Articulatory practice begins at the 'nodal point'. A nodal point is a privileged sign, which succeeds to attain a paramount position among existing signs through articulation. For instance, the present position of REDD+ in climate discourse reduces the individual role of deforestation, conservation, economic benefit from forest and introduces it as a solution to social as well as ecological problems: as a 'quick fix' to uplift rural livelihoods.

A nodal point gains exclusive status through articulation of elements. An element is also a sign whose meaning is yet to be fixed by a nodal point. The elements or signs whose meaning had been fixed by discourse are called moments. At present, especially where the donor funded REDD+ pilot projects are implemented in Nepal, deforestation, climate change in general, carbon sequestration, poverty reduction, and to some extent, aid mechanism are the elements or moments, whose individual discourses are reduced by REDD+ discourse and/or are waiting for proper definition. In this sense, all moments are 'signs' because their meaning are being fixed by ongoing discourse. They are polysemous (diversity of meanings) at this stage. There is a temporary halt to the fluctuation in the meaning of sign between elements and moments, which is called closure. In addition, those signs which are not in the position of elements or moments or which are open to different ascriptions of meaning are called floating signifiers. For instance, the role of Community Forestry User Groups (CFUGs) in REDD+ (Maraseni et al. 2014; Poudel 2014), traditional practice of forest, possibility of recentralisation of forest management, government's intervention through establishing new mechanism of forest management such as declaring conservation areas (Paudel et al. 2012), are some of the floating signifiers in the context of REDD+ in Nepal.

In this sense, REDD+, a nodal point, itself can be seen as a floating signifier, because it is under discussion in the climate discourse and has not achieved a hegemonic ${ }^{3}$ status yet. Hegemony is... social consensus achieved without recourse to violence or coercion......, and, it is achieved through articulation (cited in Rear 2013: 7). Hegemony works to mask people's real interests (Jørgensen and Phillips 2010). When a discourse attains a hegemonic status, it functions like a natural order or is institutionalised by society and becomes 'common sense' of practitioners. Then, forest communities fail to judge it as the result of international or national hegemonic practice.

A discourse is the result of social practices. All social phenomena and events can be seen as the outcomes of discursive practices. As mentioned earlier, the meaning of words depends on their context of use and acquires new status with different meanings in different contexts. So the use of language is also a social phenomenon, which is expressed through conventions, negotiations, and conflicts (Dittmer 2010). The creation of meaning through social practice is about the 'fixation' of meaning in Laclau and Mouffe's sense. In their discourse theory, all the actions of individuals are bounded or limited by discourses. There is no room for anti-discourse.

A nodal point reduces the possibility of expansion of meaning of elements. This is called the process of exclusion in Laclau and Mouffe's terms. When the associated elements and floating signifiers get meaning on the basis of the nodal point, this is called the field of discursivity by them (Jørgensen and Phillips 2010). The field of discursivity also reduces the possibility of expansion of other evolving

\footnotetext{
${ }^{3}$ Antonio Gramsci (1891-1937), an Italian, coined the term 'hegemony'. The term 'hegemony', according to him, denotes the predominance of one social class in society. It not only represents political and economic dominancy but also denotes the dominant class which can even project their own understandings of the world, and could be 'natural' and 'common sense' to subordinated classes of society (cited from http://www.aber.ac.uk/media/Documents/marxism/marxism10.html).
} 
discourses. For instance, REDD+ may motivate the local communities to increase forests and provide them fast growing trees in order to sequester more carbon without considering their usefulness in order to maintain agro-forestry farming. REDD+ may also ignore the potential impacts on the local communities due to the expansion of forestland, such as animal encroachment on agriculture land, encroachment of private land, and forced migration. These elements are not considered as discourses according to Laclau and Mouffe's theory but can be potential discourses and can challenge the REDD+ process in the future.

The field of discursivity corrals individual importance of elements or signs. Jørgensen and Phillips (2010) say that the field of discursivity is a reservoir for the 'surplus of meaning' produced by the articulatory practice - that is, the meanings that each sign has, or has had, in other discourses, but which are excluded by the specific discourse in order to create a unity of meaning. For instance, in Nepal, the role of CFUG, traditional practice of communities, and the possibility of recentralisation of forestry are in the shadow of REDD+ discourse.

A discourse becomes recognizable through establishing a chain of equivalence of meaning of elements and floating signifiers or assigning meaning to 'signs'. The chain of equivalence links floating signifiers to create identity by filling meaning on them. For instance, REDD+ discourse becomes apparent through the so-called new approach to forest management: the individual role of community's participation, biodiversity conservation, and carbon sequestration are under the aegis of REDD+ scheme. The nodal point produces meaning by defining associate elements through a chain of equivalence. This is how a discourse mediates the individual role of floating signs in a specific context. A nodal discourse, then, attains a transcendent position among the existing ones and moves toward achieving a hegemonic status.
Laclau and Mouffe also distinguish between a nodal point, master signifier and a myth. Nodal point is a privileged sign, which organizes discourses like REDD+. A master signifier organizes individual and collective identities under ongoing discourses, such as interpreting forest communities as 'poor villagers.' Similarly, a myth organizes social space of people under discussion, such as poor villagers of the 'third world' countries. In brief, nodal point, master signifier and myth nourish an ongoing discourse to become hegemonic. In this sense, $\mathrm{REDD}+$ is on the way to achieve a hegemonic status by leveling or categorizing Nepalese forest communities as 'poor villagers' of the 'third world.'

In a nutshell, Laclau and Mouffe (1985) provide us with an idea about the paramount existence of contingency in social process of meaning production. No sign has fixed meaning because they are context-dependent and context-sensitive. A discourse always competes with elements to remain as a nodal point, so it is temporary in nature and has to struggle all the time for the sake of continuous existence. Laclau and Mouffe's theory has been widely applied as a typical example of post-structuralist discourse analysis. However, their theory is criticized on the following three grounds:

First, they believe that all objective realities are created by the existing discourses of society, so there is no existence of anti-discourse beyond the field of discursivity. This version of Laclau and Mouffe's discourse theory may not apply to countries like Nepal, where principles of social differentiation like class, caste, ethnicity, urban and rural play a major role. For instance, the dominant role of the Ministry, INGOs, and CSOs such as FECOFUN and NEFIN at national level (Ojha et al. 2013) may not be representative of unorganized people, such as the landless people living in forestlands, flood victims taking refuge in forest fringes, and herders and grazers during REDD+ policy process (Paudel et al. 2015). Likewise, 
their concept of 'the field of discursivity' is extremely wide which does not also allow for competing discourses. For instance, there may be other better possibilities than REDD+ in forest/climate discourses, which may be unseen at present or have already existed as elements. A few years back, REDD+ itself was an element of forest management discourse or climate change discourse.

Second, they claim that position of signs/ elements is permanently fixed but their meanings vary in the structure of signs, and meanings rely on articulatory practice within discourses. This stance is also heavily criticized because, as mentioned earlier, the meaning of forest varies if we apply it in different contexts. Similarly, the phrase 'third world' isn't any geographic location but applies to represent 'all the poor countries' of the world. The word 'west' not only means 'direction' but also denotes 'western people' (Americans, Europeans). So, both meaning and position of a word or 'sign' are contingent and denotes different meanings in different contexts.

Finally, Laclau and Mouffe do not provide any methodological tools explicitly for further study. In this context, their concept is in limbo between theory and methodology. However, their concepts of nodal point, element, moment, closure, floating signifier, exclusion, the field of discursivity, master signifier, and myth provide a new way of thinking in discourse analysis and nurture present day's critical discourse analysis, which is the subject of next section.

The methodological hiatus of discourse theory of Laclau \& Mouffe is filled by CDA. CDA is the newest version of discourse analysis. Fairclough (1995), who coined CDA, defines it as establishing connection between the properties of texts, features of discourse practice (text production, consumption and distribution), and wider sociocultural practice. In addition to linguistic discourses, such as facts about grammar and the way different grammatical structures function in different uses, CDA also focuses on a critical use of language in contentious issues of politically, socially and culturally oriented actions (Gee and Handford 2012). Fairclough (2012) says that CDA is critical and normative as well as explanatory because it not only describes the realities, but also establishes, explains and evaluates them as the effects of social structures (e. g. inequalities in wealth, income, and access to various social goods).

Fairclough (2012) sees elements are dialectically associated because they internalize each other as different but not as discrete. Discourses not only internalize social structures but also reflect them. CDA does not neglect the existence of social structures. Social practices, power relation, political activities, beliefs, values and culture are dialectically related in the social construction of meaning. Hence, change always takes place in social relations. CDA includes texts (text, visual image and sound) and analyzes them as produced and consumed (received and interpreted) in various discursive practices and views discourse as a special form of social practice, which contributes to the constitution of the social world including social identities and relations (Jørgensen and Phillips 2010). It critically investigates connection between the nature of social processes, relations (ideologies ${ }^{4}$, power relations) and properties of written or spoken texts, which are generally less obvious to people who produce and interpret them (Fairclough 1995). Jørgensen and Phillips (2010) say that CDA is 'critical' because it maintains the social world, including those social relations that involve unequal relations of power; and it contributes along the line of more equal power relations in communication processes of society.

${ }^{4}$ Ideologies are the social constructions of meaning that contribute to the production, reproduction and transformation of relations of domination, which (relations of domination) are based on social structures such as class and gender (Fairclough 1992; Chouliaraki and Fairclough 1999; cited in Jørgensen and Phillips 2010: 75). 
Fairclough says that a discourse should be seen as (1) a language text, written or spoken; (2) a discoursive practice, text production and text interpretation; and (3) a socio-cultural practice. In other words, his method of discourse analysis includes linguistic description of the text, interpretation of relationship between the productive and interpretative discursive processes and text, and explanation of the relationship between the discursive processes and social processes (Fairclough 1995). On the basis of these assumptions, he develops a three-dimensional method of discourse analysis which is very suitable to analyse the empirical data. In this method (Figure 2), he analyses the link between regular social relations and behaviours (socio-cultural practices) and text production and interpretation (articulatory practices), which are mediated by existing discourses (discursive practices).

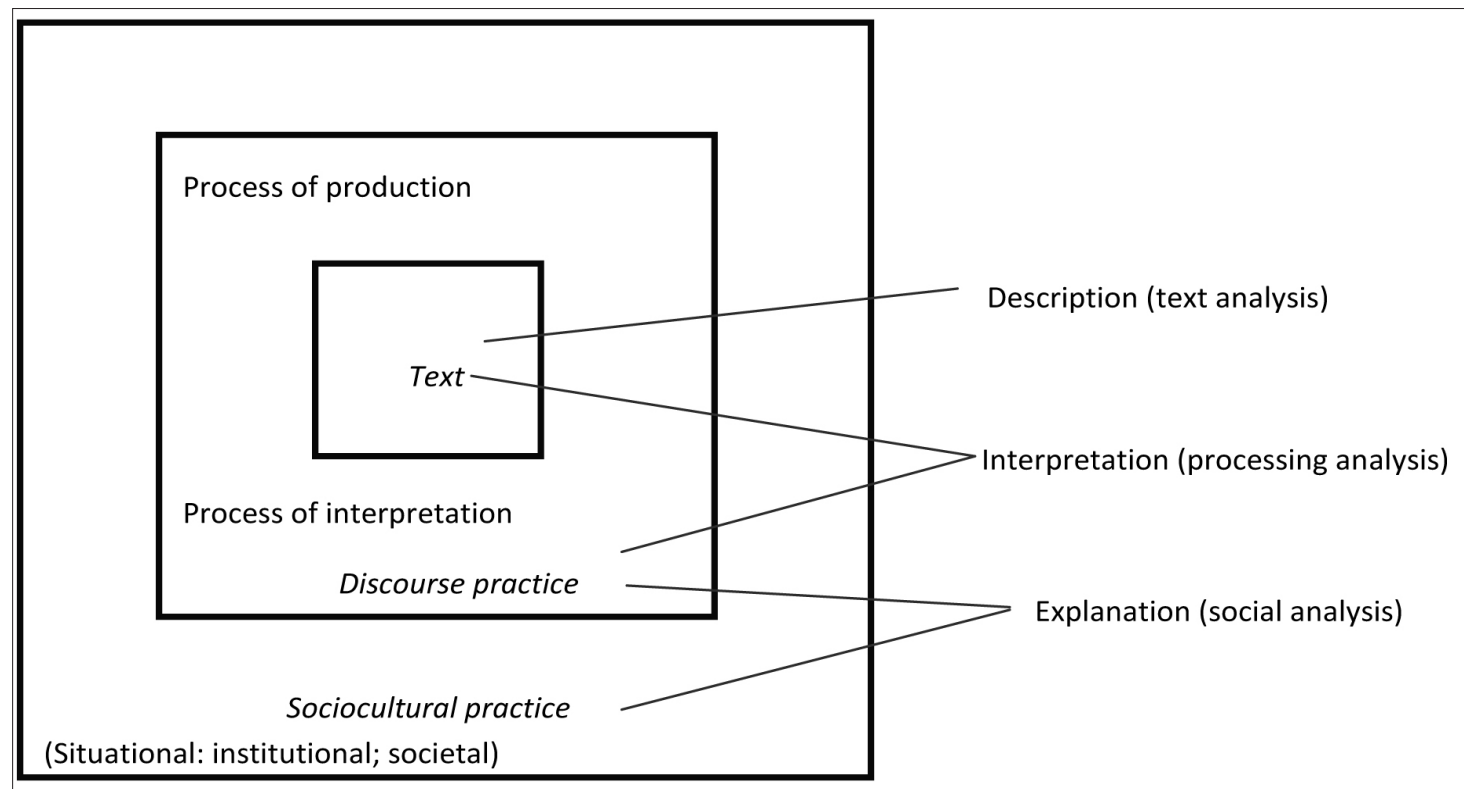

Dimensions of discourse

Dimensions of discourse analysis

Figure 2: Three-dimensional Method of Discourse Analysis (adapted from Fairclough 1995: 98)

Fairclough bridges language with society in this method in which discursive practice of society plays a pivotal role. He crystalizes a link between social structure and practices. He analyzes a discourse in three ways (text, discursive practice and social practice), where discursive practice is pivotal. A discursive practice produces, interprets and consumes texts. A discursive practice contains a discourse and a genre. A discourse can be a neo-liberal discourse, political discourse, and economic discourse whereas a genre is a particular way of using language in a specific context, such as REDD+ genre, climate genre, media genre, education genre, and health genre. Genres can be the elements of a discourse or discourses can be dealt with in relation to genres. For instance, different genres can be analysed by neo-liberal discourse. For example, when REDD+ genre is an issue, neo-liberal discourse can be added to it. Accordingly, when dealing with 'discursive practice', one should be aware of (1) how and by whom texts have been produced in relation to existing discourses and genres; (2) how these texts have been interpreted and consumed by the receivers or practitioners; and (3) how the receivers have applied these texts in their regular practice in relation to other discourses and genres. The combination of discourses and genres is called the order of discourses. 
The order of discourses is apparent in a discursive practice. For instance, the order of discourses on REDD+ may include government and donor agencies' negotiations, forest department and technical staffs relations, communication between technical staffs and forest communities, and local people's reactions. For example, following excerpt from Ojha et al. (2013) implies that the use of English language in REDD+ policy process of Nepal seriously limits the opportunity for CSOs to articulate their viewpoints;

... the REDD-Cell called a consultation meeting to share the draft framework for the national REDD interim strategy and to seek comments from stakeholders. The draft document, which was 25 pages in length and written in complicated English, was circulated to the stakeholders just a couple of days before the meeting. They were asked to read the document prior to participating in the meeting. At the meeting, the consultant presented the gist of the document (in English) and participants were asked to comment on it. The CSO representatives (FECOFUN and NEFIN) were completely lost because they could neither comprehend the draft document written in English nor fully understand the points presented by the consultant. Only a few experts made some comments and the meeting was concluded without input from the community representatives (Ojha et al. 2013: 220-221).

Discourses are dialectical. So, discourse types (discourse and genre) are pertinent in every discursive practice or while producing and consuming texts. When produced, texts are consumed or interpreted by receivers; they may be interpreted in association with or without other discourses. For instance, in the context of REDD+, forest communities may link their rights to use forest with economic and social discourses or may be with religious discourses. And later on, REDD+ may be shaped by relying on local context. So, discursive practice, which produces, consumes, and interprets texts, is a consequence of social practices. Fairclough differs from Laclau and Mouffe's theory because they have not realized the existence of non-discourse elements, whereas Fairclough believes that the existence of them is pertinent. As mentioned earlier, while dealing with REDD+ discourse, a religious discourse may come up in a specific context. The conception of interaction of different discourses and genres leads Fairclough to postulate the concept of interdiscursivity.

Interdiscursivity occurs when a new articulatory practice combines existing discourses and genres. Fairclough says that discursive reproduction and change can be investigated through an analysis of the relations between different discourses within an order of discourse and between different orders of discourses (cited in Jørgensen and Phillips 2010). Interdiscursivity is an ongoing process which never ends. For instance, prior to REDD+, climate, forest, carbon, poverty, and biodiversity were independent discourses, but REDD+ appears as sole model that manage to roll them all through one articulatory practice.

Interdiscursivity is more visible in the form of intertextuality. Intertextuality means the use of words and phrases in a new discourse which were previously used by other discourses. In other words, as Fairclough (1995) says, linguistic analysis shows how texts selectively draw upon linguistic systems, whereas textual analysis shows how texts draw upon orders of discourse. Intertextual analysis thereby draws attention to the dependence of texts upon society and history in the form of the resources made available within the order of discourses (genres, discourse, myths narratives etc.). For example, previously used texts and terminologies of climate, carbon, poverty, and biodiversity are being used to justify or to strengthen the position of REDD+. Intertextuality, thus, mediates the connection between language and social contexts and bridges the gap between texts and contexts (Fairclough 1995). 
In nutshell, Fairclough believes discourses not only constitute social structures but are also constituted by them. This is the major point where CDA is different from Laclau and Mouffe's discourse theory. For Laclau and Mouffe, society constitutes discourses and is simultaneously constituted by discourses. Furthermore, Fairclough's model explicitly suggests a method to analyze discourses in an empirical sense. Texts are impossible to understand properly in isolation. They are the reflection of social practices and existing or evolving discourses. He not only relies on (1) critical operation of linguistic feature of the texts, but also (2) sees the processes of production, interpretation and consumption of texts through discursive practices, and (3) shows the widerimplications and consequences of text production and consumption in society through the concept of socio-cultural practice.

\section{DISCUSSION AND CONCLUSION}

REDD + is not a locally originated concept. It is mothered by international donor agencies and administered by the national government, INGOs and NGOs. The role of local forest communities is blurred until now. In this context, REDD+ may re-centralize community managed forests (Gupta 2012; Phelps et al. 2010; Joshi et al. 2010) and may create conflicts locally in the future (Patel et al. 2013). This is so because forests have direct connection with the society and is considered as a kind of communal space in Nepal. More than 75 per cent of the population of Nepal relies on agriculture, and 64 per cent relies on fuelwood for cooking (CBS 2011). Three and half hectares of forests are required to maintain and protect farming of 1 hectare land in the mid hills of Nepal (Niraula et al. 2013). REDD+ should adjust to these social practices, which are presently non-discourses in order to be successfully implemented. Any changes in forest management may destabilize the sources of livelihoods of most of the population.
The concept of REDD+ has created different positions among stakeholders in Nepal, such as the local communities, government, and donor agencies. Local communities are skeptical about the recentralization of CFUGs' power through REDD+ mechanism and uncertain about their share of carbon benefits. The central government is not only in the process of policy making and negotiating with international partners and donors, but also increasing government owned forest through declaring new conservation areas. International donors are interested to distribute carbon benefits through aid mechanism. In order to scrutinize a complex situation of various stakeholders promoting different views, discourse analysis is an appropriate methodological tool to understand the REDD+ dynamics.

A discourse is a line of arguing which always tries to achieve a dominant position in society. A discourse is also a temporary fixation of meaning through articulatory practice in a specific socio-ecological context. The articulatory practice is the fixation of words or texts. Texts may be homogeneous in a general linguistic sense, but they are heterogeneous in meaning (Taylor 2013). Texts are organized in discourses not only in a strict linguistic sense, but are also related to other discourses and socio-cultural practices. In this sense, an analysis of discourse is the analysis of inter-discourses and inter-texts. For instance, REDD + is an example of a discourse about formation of a new forestry institution in developing countries like Nepal which also carries potentialities to achieve a dominant or hegemonic position. This article contends that emergence of 'REDD+' is a result of articulatory practices of international actors. Moreover, international actors can bring important lessons from outside, but they remain context sensitive and pre-empties the REDD+ debates with ready-made solutions (Ojha et al. 2013). There are currently efforts to establish it as a medium of mitigating the deteriorating climate, a new way to manage 
forests, to reduce poverty, and to conserve biodiversity in developing countries.

We suggest that discourses can be analyzed through a combination of post-structuralist and structuralist perspectives. Laclau and Mouffe (1985), representing post-structuralist perspective, consider that discourses exist prior to the social structure which create social identities and mediate perceptions about the existing realities and characteristics of phenomena. Fairclough's (1995) CDA, representing structuralist perspective, considers that discourses are bounded by preexisting social structures, so discourses also reflect them. In addition, he also considers potential existence of non-discourses and antidiscourses at the same time during discursive practice. So, in this sense, the term 'REDD+' is ostensibly being used by international actors as a panacea to convince developing nations like Nepal.

Considering 'discourse analysis' as a method and 'REDD+' as a technically articulated discourse (or a 'nodal point'), it is useful to analyze the order of discourses in so as to explore the current reality of Nepalese forest management. Combining Laclau and Mouffe's concepts of 'nodal point' and 'elements' with Fairclough's 'three-dimensional method' offers a fruitful approach to the study of REDD+ in Nepal and elsewhere. It is important to scrutinize REDD+ in a context where people consider forest as a vital source of livelihoods and the foundation of sustaining local environments.

\section{ACKNOWLEDGEMENTS}

Thanks to Norwegian State Educational Loan Fund (Lånekassen) and Department of Geography of University of Bergen for providing funding for this study. We are also equally grateful to anonymous reviewers for their constructive inputs.

\section{REFERENCES}

Angelsen, A. (Ed.). 2009. Introduction: Realizing REDD+: National Strategy and Policy Options. CIFOR, Bogor, Indonesia.

Angelsen, A. and MacNeill, D. 2012. The Evolution of REDD+. In: A. Angelsen, M. Brockhaus, W. D. Sunderlin and L. V. Verchot (Eds.), Analysing REDD+: Challenges and Choices (pp. 31-49). CIFOR, Bogor, Indonesia.

Bushley, B. R. and Khatri, D. B. 2011. REDD+: Reversing, Reinforcing or Reconfiguring Decentralized Forest Government in Nepal. Kathmandu: ForestAction Nepal.

CBS. 2011. National Population and Housing Census 2011: National Report (Vol. 1). Central Bureau of Statistics, Government of Nepal.

Chhatre, A., Lakhanpal, S., Larson, A. M., Nelson, F., Ojha, H. and Rao, J. 2012. Social Safeguards and Co-benefits in REDD+: A Review of the Adjacent Possible. Current Opinion in Environmental Sustainability, 4(6): 654-660. doi: DOI 10.1016/j. cosust.2012.08.006

Corbera, E. 2012. Problematizing REDD+ as an Experiment in Payments for Ecosystem Services. Current Opinion in Environmental Sustainability, 4(6): 612-619.

Corbera, E. and Schroeder, H. 2011. Governing and Implementing REDD+. Environmental Science and Policy, 14(2): 89-99. doi: DOI 10.1016/j. envsci.2010.11.002

Dittmer, J. 2010. Textual and Discourse Analysis. In: D. Delyser, S. Herbert, S. Aitken, M. Crang and L. McDowell (Eds.), The Sage Handbook of Qualitative Geography (pp. 274-285). SAGE.

Fairclough, N. 1995. Critical Discourse Analysis: The Critical Study of Language (1st Ed.). London and New York: Longman.

Fairclough, N. 2012. Critical Discourse Analysis. In: J. P. Gee and M. Handford (Eds.), The Routledge Handbook of Discourse Analysis (pp. 9-20). London and New York: Routledge.

Fairhead, J., Leach, M. and Scoones, I. 2012. Green Grabbing: A New Appropriation of Nature? Journal of Peasant Studies, 39(2): 237-261.

Fiske, J. 1990. Introduction to Communication Studies (Second Ed.). London and New York: Routledge.

Gee, J. P. and Handford, M. 2012. Introduction. In: J. P. Gee and M. Handford (Eds.), The Routeledge Handbook. of Discourse Analysis (pp. 6). London and New York: Routeledge.

Gupta,J. 2012. Global Forest and REDD+ Governance: Win-Win or Lose-Lose? Current Opinion in Environmental Sustainability, 4(6): 620-627. 
Jørgensen, M. W. and Phillips, L. 2010. Discourse Analysis as Theory and Method. SAGE.

Joshi, L., Sharma, N., Ojha, H, Khatri, D. B., Pradhan, R., Karky, B., Pradhan, U. and Karki, S. 2010. Moving Beyond REDD: Reducing Emissions from all Land Uses in Nepal. Final National Report (pp. 1-90). Nairobi: ASB Partnership for the Tropical Forest Margins.

Laclau, E. and Mouffe, C. 1985. Hegemony and Socialist Strategy: Towards a Radical Democratic Politics. Phronesis.

Luttrell, C., Loft, L., Gebara, M. F., Kweka, D., Brockhaus, M., Angelsen, A. and Sunderlin, W. D. 2013. Who Should Benefit from REDD Plus ? Rationales and Realities. Ecology and Society, 18(4). doi: Artn 52 Doi 10.5751/Es-05834-180452

Maraseni, T. N., Neupane, P. R., Lopez-Casero, F. and Cadman, T. 2014. An Assessment of the Impacts of the REDD+ Pilot Project on Community Forests User Groups (CFUGs) and their Community Forests in Nepal. Journal of Environmental Management, 136: 37-46. doi: http:// dx.doi.org/10.1016/j.jenvman.2014.01.011

Niraula, R. R., Gilani, H., Pokharel, B. K. and Qamer, F. M. 2013. Measuring Impacts of Community Forestry Program through Repeat Photography and Satellite Remote Sensing in the Dolakha district of Nepal. Journal of Environmental Management, 126: 20-29. doi: http://dx.doi. org/10.1016/i.jenvman.2013.04.006

Ojha, H. R., Khatri, D., Shrestha, K. K., Bushley, B. and Sharma, N. 2013. Carbon, Community and Governance: Is Nepal Getting Ready for REDD+? Forests, Trees and Livelihoods, 22(4): 216229. doi: $10.1080 / 14728028.2013 .856166$

Patel, T., Dhiaulhaq, A., Gritten, D., Yasmi, Y., De Bruyn, T., Paudel, N. S., Luintel, H., Khatri, D. B., Silori, C. and Suzuki, R. 2013. Predicting Future Conflict under REDD plus Implementation. Forests, 4(2): 343-363. doi: 10.3390/F4020343

Paudel, N. S., Jana, S. and Khatiwada, B. 2012. Contestation and Citizen-led Negotiation Around the Establishment of Protected Areas in Nepal Himalaya. Journal of Forest and Livelihood, 10(1): 4157.

Paudel, N. S., Vedeld, P. O. and Khatri, D. B. 2015. Prospects and Challenges of Tenure and Forest Governance Reform in the Context of REDD Plus Initiatives in Nepal. Forest Policy and Economics, 52: 1-8. doi: 10.1016/j.forpol.2014.12.009

Phelps, J., Webb, E. L. and Agrawal, A. 2010. Does REDD+ Threaten to Recentralize Forest Governance? Science, 328(5976): 312-313. doi: 10.1126/science. 1187774

Pokorny, B., Scholz, I. and de Jong, W. 2013. REDD Plus for the Poor or the Poor for REDD Plus ? About the Limitations of Environmental Policies in the Amazon and the Potential of Achieving Environmental Goals through Pro-poor Policies. Ecology and Society, 18(2). doi: Unsp 3 Doi 10.5751/ Es-05458-180203

Poudel, D. P. 2014. REDD+ Comes with Money, Not with Development: An Analysis of Post-pilot Project Scenarios from the Community Forestry of Nepal Himalaya. International Journal of Sustainable Development and World Ecology, 21(6): 552-562. doi: 10.1080/13504509.2014.970242

Poudel, M., Thwaites, R., Race, D. and Dahal, G. R. 2014. REDD Plus and Community Forestry: Implications for Local Communities and Forest Management- A Case Study from Nepal. International Forestry Review, 16(1): 39-54.

Rear, D. 2013. Laclau and Mouffe's Discourse Theory and Fairclough's Critical Discourse Analysis: An Introduction and Comparison. (http://www. academia.edu/2912341/Laclau_and_Mouffes_ Discourse_Theory_and_Faircloughs_Critical_ Discourse_Analysis_An_Introduction_and_ Comparison accessed on 15 January, 2015)

Searle, J. R. 2005. What is an Institution? Journal of Institutional Economics, 1(1): 1-22.

Taylor, S. 2013. What is Discourse Analysis? London: Bloomsbury.

UNFCCC. 2006. Report of the Conference of the Parties on its Eleventh Session, held at Montreal from 28 November to 10 December 2005 (FCCC/CP/2005/5). United Nations Framework Convention on Climate Change.

Venter, O. and Koh, L. P. 2012. Reducing Emissions from Deforestation and Forest Degradation (REDD+): Game Changer or Just another Quick Fix? Year in Ecology and Conservation Biology, 1249: 137-150. doi: 10.1111/j.1749-6632.2011.06306.x

Visseren-Hamakers, I. J., Gupta, A., Herold, M., Pena-Claros, M. and Vijge, M. J. 2012. Will REDD+ work? The need for Interdisciplinary Research to Address Key Challenges. Current Opinion in Environmental Sustainability, 4(6): 590-596. doi: 10.1016/j.cosust.2012.10.006

Wallbott, L. 2014. Indigenous Peoples in UN REDD+ Negotiations: "Importing Power" and Lobbying for Rights through Discursive Interplay Management. Ecology and Society, 19(1). doi: 10.5751/ES-06111190121

Wolf, S. 2013. Climate Politics as Investment: From Reducing Emissions to Building Low-carbon Economies. Wiesbaden: Springer Fachmedien Wiesbaden.

Wollenberg, E. and Springate-Beginski, O. 2010. Introduction. In: O. Springate-Beginski and E. Wollenberg (Eds.), REDD, Forest Governance and Rural Livelihoods: The Emerging Agenda. Cifor, Bogor, Indonesia. (http://www.cifor.org/publications/ pdf_files/Books/BWollenberg0101.pdf accessed on 6 June, 2013) 